\title{
EDITORIAL
}

\section{LUIZ V. DÉCOURT, ÍCONE DO HUMANISMO CIENTÍFICO}

O Prof. Dr. Luiz V. Décourt deixou-nos, aos 95 anos de idade, em Maio. Há 25 anos afastado da vida Acadêmica, por força da lei, deixa um vazio que não se preenche com facilidade. Este número de CLINICS é dedicado à sua memória. Aqui na velha Revista do HC

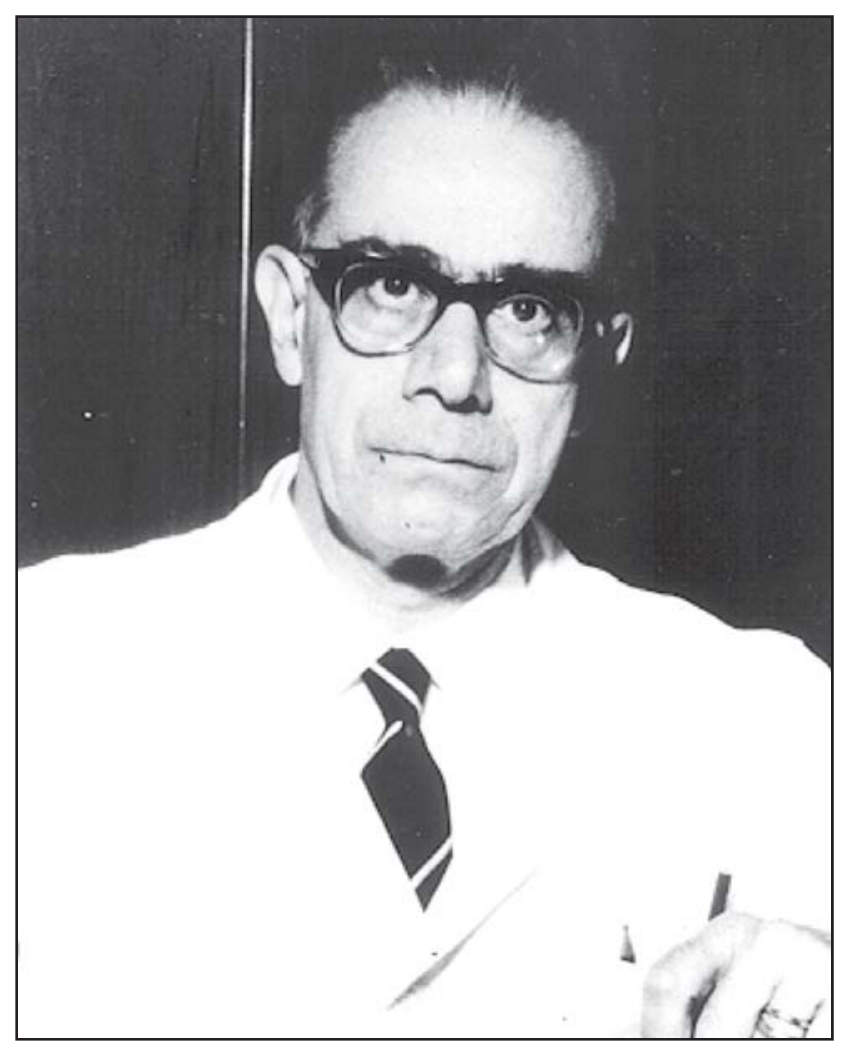

Luiz V. Décourt

(*7 de dezembro de $1911 \dagger 21$ de maio de 2007)

Entrei na casa de Arnaldo em 1965, como carinhosamente chamamos a Faculdade de Medicina da Universidade de São Paulo, inaugurada por Arnaldo Vieira de Carvalho. A Congregação era àquele tempo composta apenas dos Professores Catedráticos, por nós encarados com profundo respeito, às vezes excessivo, beirando a reverência. Éra- que foi sua também, entendemos que sua memória será mais bem reverenciada pelo depoimento emocionado do ex-aluno, hoje docente ilustre, do que com a rememoração sistemática de todos os seus grandes feitos, de resto conhecidos de todos.

mos garotos idealistas, e neles não enxergávamos defeitos, apenas virtudes. Formei-me em 1970, tendo passado como aluno por todos eles, Odorico Machado de Sousa, Isaías Raw, Carlos da Silva Lacaz, Luiz V. Décourt, Euryclides de Jesus Zerbini, Eurico da Silva Bastos, Edmundo Vasconcelos, Antonio de Barros Ulhoa Cintra, Arrigo Raia, Emilio Mattar, Sebastião de Almeida Prado Sampaio, Flavio Pires de Camargo e outros, ícones de nossa Medicina. Logo, tornei-me residente e preceptor de Clínica Médica, e meu contato com o Prof. Décourt tornou-se diário, como integrante do grupo que o rodeava nas atividades acadêmicas. Mais tarde, assistente da $2^{\mathrm{a}}$ Clínica Médica, nosso contato aumentou mais. Aos poucos, desfez-se a aura de Professor Catedrático, revelando-se para mim a imagem do homem. Não vivia apenas dentro da medicina, mas também para a Medicina, pertencia a um Universo que poucos atingem. Discutia-se ali História, Filosofia, Vinhos e Música, principalmente, Música. Mas Décourt foi sempre uma presença para poucos, pois sua vida social era restrita. Nunca foi homem da mídia, abominava o "marketing", cresceu e fez-se grande pela via de silenciosa discrição. Foi raríssimo exemplo de reconhecimento sem precisar de força ou propaganda. Era simplesmente um humanista. Como Cícero, acreditava na consciência ética com que fomos dotados pela natureza, que gera a justiça autêntica e universal, baseada não no interesse próprio, de pessoas ou de povos. Atitude talvez utópica, mas certamente exemplar. Com o tempo, muitos dos outros ídolos caíram, vítimas da soberba, da vaidade, da mesquinharia, do interesse próprio, dos jogos políticos rasteiros. Décourt, o sábio, era humilde e a Academia nunca foi para ele um meio, mas sim um fim. Nunca a usou para ganho próprio, tendo sempre vivi- 
do de forma simples. Sua imagem cresceu ininterrupta, natural e espontânea. Era autoridade pela força da pessoa, e não do cargo. Não conheço alguém que tenha feito mais discípulos do que ele. Muitos podem ter se perdido no caminho, mas a maioria permaneceu fiel aos ideais do mestre, perpetuando aquela forma determinada de consciência. Essa é a mais nobre das heranças humanas: cultural, moral e ética. Como Francisco de Assis, viveu a serviço da dignidade humana. Como Tomas de Aquino, jamais esqueceu a necessidade de respeitar a tradição construtiva. Com os exemplos que hoje nos rodeiam, onde mais vale a forma que o conteúdo, ele estaria fora da moda. Seu perfil, porém, independe de moda, pois, clássico que é, será sempre atual. Deixou-nos numa época em que a educação e a saúde tornaram-se simples mercadorias, que existem apenas em função de sua capacidade de gerar lucros materiais. Mas seguia Rousseau, em seu pensamento de que "o forte nunca é bastante forte para permanecer sempre no poder, se não transforma sua força em direito". Direito de todos e para todos. Sabia ouvir, mas era cerebralmente intolerante com a intolerância alheia. Outros tiveram poder para modificar, fazer evoluir, construir de forma desinteressada, mas decepcionaram.

Décourt sempre soube que a verdadeira educação é de cunho moral, e não técnica. Construiu um paradigma de caráter, construindo alunos, médicos, ciência, cultura. A Segunda Clínica Médica, da qual muito se orgulhava, foi sua herança, da qual também nos orgulhamos. Costumava dizer que havia uma "mística" nessa Clínica, demonstrando apego e paixão pelo ambiente de trabalho, onde reuniu e agregou um enorme número de profissionais altamente produtivos, plantando as sementes do que viria a ser o Instituto do Coração, do qual foi o primeiro Diretor Científico, em integração com Zerbini, o primeiro Diretor.

E o médico Décourt quem era afinal? Na verdade, nada mais que um clínico com impressionante visão geral. Nada menos que o hoje mais nos falta, o clínico de família, o conselheiro médico, o "amigo". Como dizia Agostinho, "aquele com que se pode compartilhar os segredos do coração". Aliava a ciência à arte do contato humano. Seus discípulos se recordam muito bem de suas exigências quanto ao respeito aos pacientes, àqueles que sofrem. Exigia informações completas, antes de recorrer às técnicas de laboratório.

Morreu materialmente pobre, mas deixa-nos lições que fazem parte dos alicerces da vida. Sua missão está cumprida, e seguramente descansa em paz. O que mais poderia alguém desejar? Com Sófocles, podemos filosofar que de ninguém deve dizer-se que é feliz antes que se tenha completado os dias de sua existência mortal. Luiz Décourt é um desses imortais raros.

Charles Mady, Instituto do Coração do Hospital das Clínicas da Faculdade de Medicina da Universidade de São Paulo. 